\title{
A Paclitaxel-Eluting Stent for the Prevention of Coronary Restenosis
}

\author{
Seung-Jung Park, M.D., Ph.D., Won Heum Shim, M.D., Ph.D., \\ David S. Ho, M.B., B.S., Ph.D., Albert E. Raizner, M.D., \\ Seong-Wook Park, M.D., Ph.D., Myeong-Ki Hong, M.D., Ph.D., \\ Cheol Whan Lee, M.D., Ph.D., Donghoon Choi, M.D., Yangsoo Jang, M.D., Ph.D., \\ Ricky Lam, M.D., Neil J. Weissman, M.D., and Gary S. Mintz, M.D.
}

\section{ABSTRACT}

\section{BACKGROUND}

Intimal hyperplasia and resulting restenosis limit the efficacy of coronary stenting. We studied a coronary stent coated with the antiproliferative agent paclitaxel as a means of preventing restenosis.

\section{METHODS}

We conducted a multicenter, randomized, controlled, triple-blind study to evaluate the ability of a paclitaxel-eluting stent to inhibit restenosis. At three centers, 177 patients with discrete coronary lesions ( $<15 \mathrm{~mm}$ in length, 2.25 to $3.5 \mathrm{~mm}$ in diameter) underwent implantation of paclitaxel-eluting stents (low dose, $1.3 \mu \mathrm{g}$ per square millimeter, or high dose, $3.1 \mu \mathrm{g}$ per square millimeter) or control stents. Antiplatelet therapies included aspirin with ticlopidine (120 patients), clopidogrel (18 patients), or cilostazol (37 patients). Clinical follow-up was performed at one month and four to six months, and angiographic follow-up at four to six months.

\section{RESULTS}

Technical success was achieved in 99 percent of the patients (176 of 177). At follow-up, the high-dose group, as compared with the control group, had significantly better results for the degree of stenosis (mean $[ \pm S D], 14 \pm 21$ percent vs. $39 \pm 27$ percent; $\mathrm{P}<0.001)$, late loss of luminal diameter $(0.29 \pm 0.72 \mathrm{~mm}$ vs. $1.04 \pm 0.83 \mathrm{~mm}, \mathrm{P}<0.001)$, and restenosis of more than 50 percent ( 4 percent vs. 27 percent, $\mathrm{P}<0.001$ ). Intravascular ultrasound analysis demonstrated a dose-dependent reduction in the volume of intimal hyperplasia $\left(31,18\right.$, and $13 \mathrm{~mm}^{3}$, in the high-dose, low-dose, and control groups, respectively). There was a higher rate of major cardiac events in patients receiving cilostazol than in those receiving ticlopidine or clopidogrel. Among patients receiving ticlopidine or clopidogrel, event-free survival was 98 percent and 100 percent in the high-dose and control groups, respectively, at one month, and 96 percent in both at four to six months.

\section{CONCLUSIONS}

Paclitaxel-eluting stents used with conventional antiplatelet therapy effectively inhibit restenosis and neointimal hyperplasia, with a safety profile similar to that of standard stents.
From the Asan Medical Center (S.-J.P., S.-W.P., M.-K.H., C.W.L.) and Yonsei Medical Center (W.H.S., D.C., Y.J.) - both in Seoul, South Korea; the University of Hong Kong, Hong Kong, China (D.S.H., R.L.); the Cardiovascular Angiography Analysis Laboratory, Houston (A.E.R.); the Cardiovascular Research Institute, Washington Hospital Center, Washington, D.C. (N.J.W.); and the Cardiovascular Research Foundation, New York (G.S.M.). Address reprint requests to Dr. Seung-Jung Park at the Asan Medical Center, Division of Cardiology, 388-1 Poongnap-dong, Songpa-ku, Seoul 138-736, South Korea, or at sjpark@amc.seoul.kr.

N EnglJ Med 2003;348:1537-45.

Copyright $\odot 2003$ Massachusetts Medical Society. 
I

NTIMAL HYPERPLASIA AFTER STENT PLACEment and the resultant restenosis remain problematic despite numerous improvements in stent technology and placement technique. ${ }^{1-5}$ In the past decade, stents coated with antiproliferative agents have been the focus of considerable research because of their potential for eliminating restenosis. Although many agents have failed preclinical testing, paclitaxel and sirolimus (rapamycin) have proceeded to clinical studies. ${ }^{6-9}$ In a previously published study, sirolimus showed promise in reducing restenosis. ${ }^{7}$ We present a randomized study of paclitaxel-coated stents.

Paclitaxel inhibits cell processes that are dependent on microtubule turnover, including mitosis, cell proliferation, and cell migration, while the cells remain viable and in a cytostatic state. ${ }^{10-14}$ In vitro tests show cytostatic inhibition of smoothmuscle cells with therapeutic concentrations of paclitaxel. For this reason, paclitaxel was considered for intracoronary delivery to arrest the process responsible for neointimal hyperplasia after angioplasty and stenting. ${ }^{14-17}$

Preclinical testing using a porcine coronaryartery model showed inhibition of neointimal hyperplasia at one month over a range of doses, all with acceptable safety. Although delayed endothelialization was noted on histologic examination, reinforcing the need for antiplatelet therapy, results did not suggest subacute thrombotic complications while patients were receiving ticlopidine. In a subsequent six-month study in which ticlopidine was discontinued one month after stent implantation, there were no late deaths from stent thrombosis. Given this promising evidence of effectiveness and acceptable safety profile, further study was considered to be warranted.

We designed a multicenter, prospective, randomized study to test the hypothesis that stents coated with paclitaxel would inhibit neointimal hyperplasia in patients with coronary artery disease requiring stenting of single new native lesions. Our study, the Asian Paclitaxel-Eluting Stent Clinical Trial (ASPECT), compared the safety and effectiveness of paclitaxel-eluting stents with the safety and effectiveness of uncoated stents of the same type.

METHODS

SELECTION OF PATIENTS

Symptomatic patients were included if they were at least 18 years old and volunteered for follow-up.
Criteria for exclusion included an ejection fraction of less than 35 percent; coagulopathy; intractable hypersensitivities; the performance of other studies within the previous 30 days; pregnancy; a life expectancy of less than 1 year; myocardial infarction within the previous 72 hours; other revascularization procedures within the previous 1 month; the presence of coronary thrombus; severe calcification; total occlusion; another stenosis of more than 50 percent in the target vessel; a lesion length greater than $15 \mathrm{~mm}$; multiple stents; proximal tortuosity; angulation of more than 45 percent; unprotected left-main coronary lesions; and poor distal runoff. The protocol was approved by the appropriate ethics committees. Participants gave written informed consent, and the study was conducted between January 2000 and March 2001 in accordance with the Declaration of Helsinki.

\section{STUDY DESIGN}

The three-center randomized study compared stents coated with one of two doses of paclitaxel with an uncoated control stent of the same design. The study population was stratified according to stent diameter and was randomized in blocks (in a ratio of 1:1:1). Stents (Cook) of each diameter were ordered in a randomized sequence. After angiography to determine vessel diameter, stents of the appropriate diameter were selected in order of sequence. The patients, investigators, and core-analysis laboratories were all unaware of the random group assignments.

\section{ANGIOPLASTY AND STENTING PROCEDURE}

Standard angioplasty and stent placement were performed with a radial or femoral approach and an over-the-wire technique. Lesions were predilated with a standard balloon equal to or smaller than the diameter of the reference vessel. The stent, premounted on a semicompliant balloon, was chosen to achieve a stent-to-artery ratio of approximately 1.1:1.0. The stent was delivered by low-pressure inflation and dilated if necessary to achieve minimal residual stenosis ( $<10$ percent). In the event of a distal or proximal dissection, a second uncoated stent of either the study type or another type was placed.

The stent used in the study was a 15-mm-long Supra-G stent (Cook) in diameters of 2.5, 3.0, and $3.5 \mathrm{~mm}$. The polished stainless-steel, laser-cut cannula design had a large surface area (42 to $47 \mathrm{~mm}^{2}$, depending on the diameter). A proprietary process was used to bond paclitaxel, at a dose density 
of 3.1 $\mu \mathrm{g}$ per square millimeter or $1.3 \mu \mathrm{g}$ per square millimeter, to the abluminal surface of the stents without the use of a polymer. The total amount of paclitaxel per stent was 130 to $146 \mu \mathrm{g}$ in the group that received stents with the dose of $3.1 \mu \mathrm{g}$ per square millimeter and 54 to $60 \mu \mathrm{g}$ in the group that received stents with the dose of $1.3 \mu \mathrm{g}$ per square millimeter, depending on the diameter of the stent.

The protocol recommended treatment with soluble aspirin and clopidogrel or ticlopidine before the procedure. Heparin was administered during the procedure according to standard practice. After the procedure, in addition to aspirin, ticlopidine or clopidogrel was recommended for one month at two centers and for six months at the third center. Cilostazol ${ }^{18-20}$ was administered in lieu of ticlopidine or clopidogrel in 37 patients, as was standard practice for patients with stents at two centers.

\section{STUDY END POINTS}

Clinical follow-up was performed at one month and again at four to six months; angiographic follow-up was performed at four to six months. The primary end point was the percentage stenosis at angiographic follow-up, as determined by independent quantitative angiographic analysis. Secondary angiographic end points included late loss, the rate of restenosis (defined as stenosis of more than 50 percent of the luminal diameter), and the in-stent minimal luminal diameter. Secondary clinical end points included the incidence of death, acute and subacute thrombosis, the need for coronary bypass surgery or intervention to treat clinical ischemia due to restenosis of the target lesion, and myocardial infarction (Q-wave or non-Q-wave) due to restenosis of the target lesion. Q-wave myocardial infarction was defined by the postprocedural presence of new $Q$ waves greater than 0.04 second in two contiguous leads. Non-Q-wave myocardial infarction was defined as investigator-identified, clinically significant myocardial infarction involving peak creatine kinase values greater than twice the upper limit of normal and a creatine kinase MB fraction greater than twice the upper limit of normal.

Clinical events were adjudicated by an independent clinical-events committee (Harvard Clinical Research Institute, Boston). Safety data were reviewed by an independent data safety monitoring board (Willis Tacker, M.D., Ph.D., Seattle, Chairman). Data were collected with standardized case-report forms that were completed by the research coordinator at each site. Representatives from the data-coordinating center monitored the sites.

\section{AN GIOGRAPHIC ANALYSIS}

Procedural and follow-up angiograms were submitted to an independent angiographic core laboratory (Methodist Hospital, Houston). Quantitative angiographic analysis was performed (CAAS II, Pie Medical) for standard qualitative and quantitative characteristics such as luminal dimensions, including proximal and distal references, and the minimal luminal diameter before and after the procedure and at follow-up. Angiograms were evaluated qualitatively for morphologic features of the lesion, flow grade, dissection grade, and branches larger than $2 \mathrm{~mm}$.

\section{INTRAVASCULAR-ULTRASOUND SUBSTUDY}

Eighty-one patients at one center underwent an intravascular-ultrasound substudy designed to provide more detailed information about the mechanism of inhibition of restenosis. Automatic pullback images were obtained after stent placement and at four to six months of follow-up. Imaging extended up to $5 \mathrm{~mm}$ distally and $5 \mathrm{~mm}$ proximally in most patients. The postprocedural and follow-up images were submitted to an independent, blinded core laboratory (Cardiovascular Research Institute, Washington, D.C.) for analysis. Luminal, stent, vessel, and neointimal volumes were calculated from automated pullback images with use of Simpson's rule with $1-\mathrm{mm}$ intervals.

\section{STATISTICAL ANALYSIS}

The study was designed by the academic investigators and commercial sponsor and had sufficient power to detect a 15 percent difference in the angiographically determined percentage of stenosis at six months, for an alpha level of 0.05 and a beta of 0.20 ; it was calculated that a minimum of $50 \mathrm{pa}-$ tients was required per treatment group, assuming a 90 percent follow-up.

Continuous variables are reported as means $\pm S D$. Effects across all three groups were analyzed by analysis of variance, and pairwise comparisons were performed with an unpaired t-test. Dichotomous variables are reported as percentages with 95 percent confidence intervals; comparisons were performed with a Pearson's chi-square or Fisher's exact test. Analysis was performed on an intention-totreat basis including all patients for whom data were available from the follow-up analysis. All data 
were available to the investigators, and the data analysis was performed independently of the sponsor.

\section{RESULTS}

DEMOGRAPHIC AND CLINICAL CHARACTERISTICS Between January 2000 and March 2001, 177 patients were enrolled: 60 in the high-dose group, 58 in the low-dose group, and 59 in the control group. Stent implantation was successful in 176 patients (99.4 percent); 1 patient did not receive a stent because of tortuosity. Analysis of demographic and base-line characteristics showed no significant differences among groups (Table 1). The patients' characteristics were typical of those of patients with noncomplex lesions. Multivessel disease was present in 40 percent of the patients. The lesions treated are described qualitatively and quantitatively as assessed by the independent core laboratory in Table 2; no significant differences existed among the groups.

\begin{tabular}{|c|c|c|c|c|}
\hline \multirow[t]{2}{*}{ Variable } & \multicolumn{3}{|c|}{ Dose of Paclitaxel } & \multirow[t]{2}{*}{$\begin{array}{c}\text { Total } \\
(\mathrm{N}=177)\end{array}$} \\
\hline & $\begin{array}{c}3.1 \\
\mu \mathrm{g} / \mathrm{mm}^{2} \\
(\mathrm{~N}=60)\end{array}$ & $\begin{array}{c}1.3 \\
\mu \mathrm{g} / \mathrm{mm}^{2} \\
(\mathrm{~N}=58)\end{array}$ & $\begin{array}{c}0 \\
\mu \mathrm{g} / \mathrm{mm}^{2} \\
(\mathrm{~N}=59)\end{array}$ & \\
\hline Age $-y r$ & $58 \pm 9$ & $60 \pm 9$ & $58 \pm 11$ & $60 \pm 10$ \\
\hline Male sex - no. (\%) & $48(80)$ & $42(72)$ & $45(76)$ & $135(76)$ \\
\hline Diabetes mellitus — no. (\%) & $11(18)$ & $14(24)$ & $10(17)$ & $35(20)$ \\
\hline Hypercholesterolemia - no. (\%) & $8(13)$ & $4(7)$ & $11(19)$ & $23(13)$ \\
\hline Hypertension - no. (\%) & $25(42)$ & $31(53)$ & $28(47)$ & $84(47)$ \\
\hline $\begin{array}{l}\text { Smoking - no. (\%) } \\
\text { Never } \\
\text { Past } \\
\text { Current } \\
\text { Unknown }\end{array}$ & $\begin{array}{r}21(35) \\
8(13) \\
28(47) \\
3(5)\end{array}$ & $\begin{array}{c}23(40) \\
11(19) \\
23(40) \\
1(2)\end{array}$ & $\begin{array}{r}24(41) \\
8(14) \\
27(46) \\
0\end{array}$ & $\begin{array}{c}68(39) \\
27(15) \\
78(44) \\
0\end{array}$ \\
\hline Obesity — no. (\%) & $5(8)$ & $3(5)$ & $1(2)$ & $9(5)$ \\
\hline $\begin{array}{l}\text { Prior myocardial infarction } \\
\text { - no. (\%) }\end{array}$ & $14(23)$ & $13(22)$ & $17(29)$ & $44(25)$ \\
\hline $\begin{array}{l}\text { Prior coronary-artery bypass graft } \\
\qquad \text { - no. (\%) }\end{array}$ & $2(3)$ & $1(2)$ & 0 & $3(2)$ \\
\hline \multicolumn{5}{|l|}{ No. of diseased vessels — no. (\%) } \\
\hline 1 & $32(53)$ & $36(62)$ & $39(66)$ & $107(60)$ \\
\hline 2 & $20(33)$ & $17(29)$ & $15(25)$ & $52(29)$ \\
\hline 3 & $8(13)$ & $4(7)$ & $5(8)$ & $17(10)$ \\
\hline 4 & 0 & $1(2)$ & 0 & $1(1)$ \\
\hline
\end{tabular}

* There were no significant differences among the treatment groups. Plus-minus values are mean \pm SD.
At discharge, all but one patient received aspirin, and no patient received warfarin. In addition to aspirin, 120 received ticlopidine after the procedure and at discharge ( 26 for one month and 94 for six months); of these, 1 also received postprocedural abciximab, and 3 also received postprocedural standard heparin. Eighteen received clopidogrel for one month, without postprocedural abciximab or heparin. Thirty-seven received cilostazol (29 for one month and 8 for six months); 1 also had abciximab after the procedure, and 3 had standard heparin after the procedure. One patient received aspirin and ticlopidine after the procedure but did not take aspirin or ticlopidine after discharge, because of clinically significant urethral bleeding.

\section{ANGIOGRAPHIC OUTCOMES}

Angiographic measures are shown in Table 3; angiographic follow-up was obtained for 155 patients ( 88 percent), at a mean of $174 \pm 44$ days (range, 85 to 412 , including early symptomatic interventions). The results demonstrated a dose-dependent reduction in the primary end point, the percentage of stenosis (39 \pm 27 percent in the control group, vs. $23 \pm 25$ percent in the low-dose group and $14 \pm 21$ percent in the high-dose group; $\mathrm{P}<0.001$ ).

Late loss of luminal diameter involved a dosedependent reduction as well $(1.04 \pm 0.83 \mathrm{~mm}$ in the controls, $0.57 \pm 0.71 \mathrm{~mm}$ in the low-dose group, and $0.29 \pm 0.72 \mathrm{~mm}$ in the high-dose group; $\mathrm{P}<0.001$ ). In the calculation of the late-loss index as the slope of the regression line on a graph of late loss versus acute gain, only the control group yielded a slope. In the paclitaxel groups, the correlation coefficient was near zero, indicating no relation between late loss and immediate gain (the luminal diameter immediately after the procedure minus the luminal diameter before the procedure). In lieu of a late-loss index we calculated the late loss divided by the immediate gain for each patient; this ratio was reduced from $0.46 \pm 0.37$ in the control group to $0.26 \pm 0.34$ and $0.13 \pm 0.33$ in the low-dose and high-dose groups, respectively $(\mathrm{P}<0.001)$.

The rate of restenosis, defined as stenosis of more than 50 percent, was 27 percent in the control group, 12 percent in the low-dose group, and 4 percent in the high-dose group $(\mathrm{P}<0.001)$. These reductions were associated with a dose-dependent improvement in the minimal luminal diameter $(1.79 \pm 0.86 \mathrm{~mm}$ in the controls, vs. $2.28 \pm 0.83 \mathrm{~mm}$ in the low-dose group and $2.53 \pm 0.72 \mathrm{~mm}$ in the high-dose group; $\mathrm{P}<0.001)$. 
Cumulative distribution curves demonstrated a dose-dependent reduction in the degree of stenosis, as shown in Figure 1 for the high-dose group as compared with the control group. Distributions were similar at base line and immediately after stent placement. At follow-up, the distribution in the high-dose group was similar to the distribution immediately after stenting.

\section{INTRAVASCULAR ULTRASOUND}

Intravascular-ultrasound analysis of 81 patients showed a dose-dependent reduction in the volume of neointimal hyperplasia at follow-up $\left(31 \pm 22 \mathrm{~mm}^{3}\right.$ in the controls, $18 \pm 15 \mathrm{~mm}^{3}$ in the low-dose group, and $13 \pm 14 \mathrm{~mm}^{3}$ in the high-dose group; $\mathrm{P}<0.001$ ). There were no significant differences in any volumes after the procedure, and no significant differences in stent or vessel volume at follow-up.

\section{SAFETY AT ONE AND SIX MONTHS}

Clinical follow-up was obtained for all patients who received stents at one month and four to six months

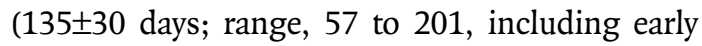
symptomatic interventions). Major adverse cardiac events are shown in Table 4. Events were classified according to antiplatelet therapy because an adverse effect of cilostazol was observed. Of 138 patients receiving ticlopidine or clopidogrel, the only event reported at one month was a non-Q-wave myocardial infarction due to closure of a side branch evident during stent placement, which was dilated. In 37 patients receiving cilostazol, there were 1 death and 4 subacute thromboses treated with repeated angioplasty within one month. Potential contributing factors included a stent shorter than the lesion, leaving a dissection uncovered, in one case, and a thrombus that was untreated after stenting in another. In each of the three groups, two patients underwent target-lesion revascularization for restenosis within six months. There were no additional events after one month, even for the 73 patients whose ticlopidine, clopidogrel, or cilostazol therapy was discontinued after only one month.

\section{I SCUSSION}

This study clearly shows that a paclitaxel-coated coronary stent can significantly reduce restenosis in the six months after intervention, thereby addressing a major problem that has plagued angioplasty since its inception and has not been adequately addressed by the introduction of stents. The dose

\begin{tabular}{|c|c|c|c|c|}
\hline \multirow[t]{2}{*}{ Variable } & \multicolumn{3}{|c|}{ Dose of Paclitaxel } & \multirow[t]{2}{*}{$\begin{array}{c}\text { Total } \\
(\mathrm{N}=176\end{array}$} \\
\hline & $\begin{array}{c}3.1 \\
\mu \mathrm{g} / \mathrm{mm}^{2} \\
(\mathrm{~N}=59)\end{array}$ & $\begin{array}{c}1.3 \\
\mu \mathrm{g} / \mathrm{mm}^{2} \\
(\mathrm{~N}=58)\end{array}$ & $\begin{array}{c}0 \\
\mu \mathrm{g} / \mathrm{mm}^{2} \\
(\mathrm{~N}=59)\end{array}$ & \\
\hline & \multicolumn{4}{|c|}{ no. (\%) } \\
\hline $\begin{array}{l}\text { Vessel stented } \\
\text { Left anterior descending } \\
\quad \text { coronary artery }\end{array}$ & $31(53)$ & $29(50)$ & $30(51)$ & $90(51)$ \\
\hline Right coronary artery & $10(17)$ & $18(31)$ & $17(29)$ & $45(26)$ \\
\hline $\begin{array}{l}\text { Left circumflex coronary } \\
\text { artery }\end{array}$ & $17(29)$ & $10(17)$ & $12(20)$ & $39(22)$ \\
\hline Ramus & $1(2)$ & $1(2)$ & 0 & $2(1)$ \\
\hline \multicolumn{5}{|l|}{ Lesion classification } \\
\hline A & $29(49)$ & $35(60)$ & $30(51)$ & $94(53)$ \\
\hline $\mathrm{Bl}$ & $26(44)$ & $21(36)$ & $24(41)$ & $71(40)$ \\
\hline B2 & $4(7)$ & $1(2)$ & $5(8)$ & $10(6)$ \\
\hline $\mathrm{C}$ & 0 & $1(2)$ & 0 & $1(1)$ \\
\hline \multicolumn{5}{|l|}{ Proximal tortuosity } \\
\hline None & $37(63)$ & $36(62)$ & $32(54)$ & $105(60)$ \\
\hline Mild & $21(36)$ & $19(33)$ & $26(44)$ & $66(38)$ \\
\hline Moderate & $1(2)$ & $3(5)$ & $1(2)$ & $5(3)$ \\
\hline Severe & 0 & 0 & 0 & 0 \\
\hline \multicolumn{5}{|l|}{ Calcification } \\
\hline None & $52(88)$ & $49(84)$ & $47(80)$ & $148(84)$ \\
\hline Mild & 7 (12) & $9(16)$ & $9(15)$ & 25 (14) \\
\hline Moderate & 0 & 0 & $3(5)$ & $3(2)$ \\
\hline Severe & 0 & 0 & 0 & 0 \\
\hline \multicolumn{5}{|l|}{ Shape } \\
\hline Concentric & $25(42)$ & $29(50)$ & $25(42)$ & $79(45)$ \\
\hline Eccentric & $34(58)$ & $29(50)$ & $34(58)$ & $97(55)$ \\
\hline Angulation $>45$ degrees & $1(2)$ & $1(2)$ & 0 & $2(1)$ \\
\hline Other stenosis & $2(3)$ & $4(7)$ & $4(7)$ & $10(6)$ \\
\hline Ostial & $1(2)$ & $1(2)$ & $1(2)$ & $3(2)$ \\
\hline Branch & $4(7)$ & $6(10)$ & $7(12)$ & $17(10)$ \\
\hline Thrombus & 0 & $1(2)$ & 0 & $1(1)$ \\
\hline
\end{tabular}

* There were no significant differences among the treatment groups.

of 3.1 $\mu \mathrm{g}$ per square millimeter was the more effective of the two doses tested and had safety similar to that of other doses within the follow-up period studied, when used with conventional antiplatelet therapy.

The intravascular-ultrasound substudy showed that the reduction in the percentage of stenosis and in late loss and the increase in the minimal luminal diameter were directly due to a reduction in the proliferation of neointimal tissue. They were not associated with a high degree of positive remodeling. 


\begin{tabular}{|c|c|c|c|c|}
\hline \multirow[t]{2}{*}{ Variable } & \multicolumn{3}{|c|}{ Dose of Paclitaxel } & \multirow[t]{2}{*}{$\begin{array}{c}\text { P Value } \\
\text { (High Dose vs. Control) }\end{array}$} \\
\hline & $3.1 \mu \mathrm{g} / \mathrm{mm}^{2}$ & $1.3 \mu \mathrm{g} / \mathrm{mm}^{2}$ & $0 \mu \mathrm{g} / \mathrm{mm}^{2}$ & \\
\hline Lesion length (mm) & $10.9 \pm 3.6$ & $11.2 \pm 3.2$ & $10.5 \pm 3.1$ & 0.52 \\
\hline Diameter of reference vessel $(\mathrm{mm})$ & $2.94 \pm 0.39$ & $2.93 \pm 0.38$ & $2.88 \pm 0.36$ & 0.69 \\
\hline $\begin{array}{l}\text { Stenosis (\% of luminal diameter) } \\
\text { Before procedure } \\
\text { After procedure } \\
\text { At follow-up }\end{array}$ & $\begin{array}{c}79.4 \pm 9.0 \\
1.87 \pm 5.38 \\
14 \pm 21\end{array}$ & $\begin{array}{c}80.1 \pm 8.0 \\
3.27 \pm 5.03 \\
23 \pm 25\end{array}$ & $\begin{array}{c}80.9 \pm 9.9 \\
3.77 \pm 8.42 \\
39 \pm 27\end{array}$ & $\begin{array}{c}0.14 \\
0.67 \\
<0.001\end{array}$ \\
\hline $\begin{array}{l}\text { Minimal luminal diameter }(\mathrm{mm}) \\
\text { Before procedure } \\
\text { After procedure } \\
\text { At follow-up }\end{array}$ & $\begin{array}{l}0.64 \pm 0.29 \\
2.85 \pm 0.34 \\
2.53 \pm 0.72\end{array}$ & $\begin{array}{l}0.57 \pm 0.25 \\
2.84 \pm 0.39 \\
2.28 \pm 0.83\end{array}$ & $\begin{array}{l}0.54 \pm 0.33 \\
2.82 \pm 0.42 \\
1.79 \pm 0.86\end{array}$ & $\begin{array}{c}0.19 \\
0.92 \\
<0.001\end{array}$ \\
\hline Late loss (mm) & $0.29 \pm 0.72$ & $0.57 \pm 0.71$ & $1.04 \pm 0.83$ & $<0.001$ \\
\hline Average loss or gain $(\mathrm{mm})$ & $0.13 \pm 0.33$ & $0.26 \pm 0.34$ & $0.46 \pm 0.37$ & $<0.001$ \\
\hline Restenosis (\% of patients) & 4 & 12 & 27 & $<0.001$ \\
\hline
\end{tabular}

* The numbers of patients for whom there were measurements before and after the procedure were as follows: 58 in the high-dose group, 57 in the low-dose group, and 57 in the control group. For follow-up measurements, the numbers were 50 in the high-dose group, 50 in the low-dose group, and 55 in the control group. Plus-minus values are means $\pm S D$.

The concept that a bigger stent is better has been predicated on the late-loss index, indicating that approximately half the immediate gain is lost within six months. ${ }^{21}$ Although other therapies such as brachytherapy ${ }^{22,23}$ have reduced the late-loss index, in this study we found a near-zero correlation coefficient for paclitaxel-eluting stents. This suggests

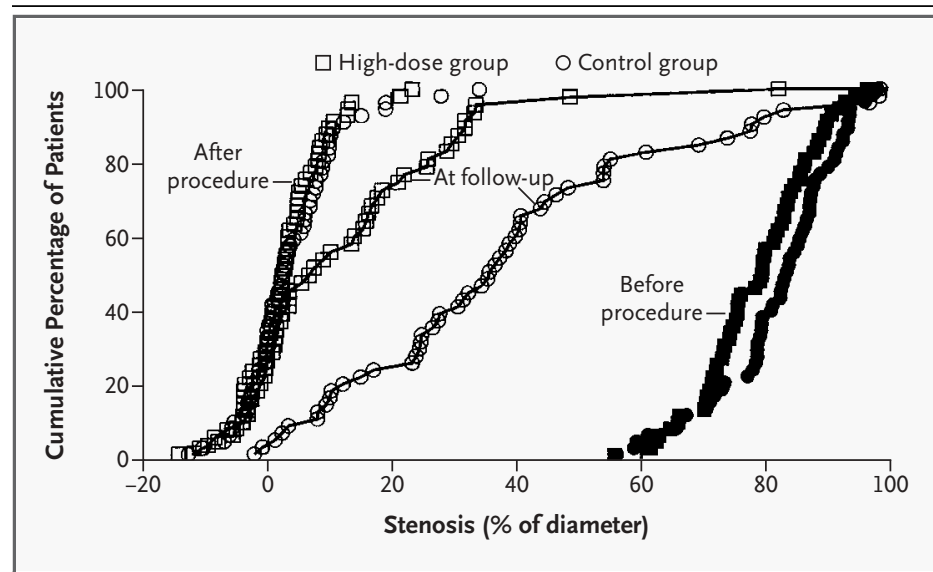

Figure 1. Cumulative Distribution of the Percentage of Stenosis in the HighDose and Control Groups.

The distributions were similar at base line and immediately after stent placement. At six months, the distribution in the high-dose group remained similar to the distribution immediately after stenting. the bigger-is-better concept may not apply to drugeluting stents.

The major adverse cardiac events within one month suggest that the paclitaxel-eluting stent is safe at both low and high dose densities if used with conventional thianopyridine antiplatelet therapy. The single event was due to closure of an involved side branch evident at the time of the procedure and therefore appeared to be unrelated to the coating. The incidence of subacute thrombotic events in patients who received cilostazol instead of ticlopidine or clopidogrel suggests that antiplatelet agents may be more important for drug-eluting stents than for uncoated stents and that cilostazol is an inadequate substitute for thianopyridines with paclitaxel-eluting stents.

The absence of additional deaths, myocardial infarctions, or emergency bypass surgeries between one and six months after the procedure suggests that the paclitaxel-eluting stent is reasonably safe during this period at the dose densities studied. The number of additional target-lesion revascularizations for restenosis was similar among treatment groups, despite the significant difference in all angiographic measures of restenosis. This apparent discrepancy was due to the pattern of clinical practice in the participating centers, in which angiographic restenosis is not treated with intervention 


\begin{tabular}{|c|c|c|c|c|c|c|c|c|c|c|c|c|}
\hline \multirow[t]{2}{*}{ Variable } & \multicolumn{4}{|c|}{$\begin{array}{l}\text { Aspirin with Ticlopidine } \\
\text { or Clopidogrel }\end{array}$} & \multicolumn{4}{|c|}{ Aspirin with Cilostazol } & \multicolumn{4}{|c|}{ All } \\
\hline & $\begin{array}{l}3.1 \mu \mathrm{g} \\
\text { of pacli- } \\
\text { taxel/ } \\
\mathrm{mm}^{2}\end{array}$ & $\begin{array}{l}1.3 \mu \mathrm{g} \\
\text { of pacli- } \\
\text { taxel/ } \\
\mathrm{mm}^{2}\end{array}$ & $\begin{array}{c}0 \mu \mathrm{g} \\
\text { of pacli- } \\
\text { taxel/ } \\
\mathrm{mm}^{2}\end{array}$ & Total & $\begin{array}{l}3.1 \mu \mathrm{g} \\
\text { of pacli- } \\
\text { taxel/ } \\
\mathrm{mm}^{2}\end{array}$ & $\begin{array}{c}1.3 \mu \mathrm{g} \\
\text { of pacli- } \\
\text { taxel/ } \\
\mathrm{mm}^{2}\end{array}$ & $\begin{array}{c}0 \mu \mathrm{g} \\
\text { of pacli- } \\
\text { taxel/ } \\
\mathrm{mm}^{2}\end{array}$ & Total & $\begin{array}{l}3.1 \mu \mathrm{g} \\
\text { of pacli- } \\
\text { taxel/ } \\
\mathrm{mm}^{2}\end{array}$ & $\begin{array}{l}1.3 \mu \mathrm{g} \\
\text { of pacli- } \\
\text { taxel/ } \\
\mathrm{mm}^{2}\end{array}$ & $\begin{array}{c}0 \mu \mathrm{g} \\
\text { of pacli- } \\
\text { taxel/ } \\
\mathrm{mm}^{2}\end{array}$ & Total'T \\
\hline No. of patients & 47 & 43 & 48 & 138 & 12 & 15 & 10 & 37 & 59 & 58 & 58 & 175 \\
\hline \multicolumn{13}{|l|}{ One-month results } \\
\hline Death (no.) & 0 & 0 & 0 & 0 & 0 & 1 & 0 & 1 & 0 & 1 & 0 & 1 \\
\hline $\begin{array}{r}\text { Coronary bypass } \\
\text { surgery (no.) }\end{array}$ & 0 & 0 & 0 & 0 & 0 & 0 & 0 & 0 & 0 & 0 & 0 & 0 \\
\hline Q-wave MI (no.) & 0 & 0 & 0 & 0 & 0 & 0 & 0 & 0 & 0 & 0 & 0 & 0 \\
\hline $\begin{array}{l}\text { Non-Q-wave MI } \\
\text { (no.) }\end{array}$ & $1 \dagger$ & 0 & 0 & $1 \%$ & 1 & 1 & 1 & 3 & 2 & 1 & 1 & 4 \\
\hline $\begin{array}{l}\text { Subacute thrombosis } \\
\text { (no.) } \int\end{array}$ & 0 & 0 & 0 & 0 & 3 & 1 & 0 & 4 & 3 & 1 & 0 & 4 \\
\hline Event-free (\%) & 98 & 100 & 100 & 99 & 75 & 87 & 90 & 84 & 93 & 97 & 98 & 96 \\
\hline \multicolumn{13}{|l|}{ Six-month results } \\
\hline Death (no.) & 0 & 0 & 0 & 0 & 0 & 1 & 0 & 1 & 0 & 1 & 0 & 1 \\
\hline $\begin{array}{r}\text { Coronary bypass } \\
\text { surgery (no.) }\end{array}$ & 0 & 0 & 0 & 0 & 0 & 0 & 0 & 0 & 0 & 0 & 0 & 0 \\
\hline Q-wave MI (no.) & 0 & 0 & 0 & 0 & 0 & 0 & 0 & 0 & 0 & 0 & 0 & 0 \\
\hline $\begin{array}{l}\text { Non-Q-wave MI } \\
\quad \text { (no.) (all } 30 \text { days) } \|\end{array}$ & $1 \dagger$ & 0 & 0 & $1 \%$ & 1 & 1 & 1 & 3 & 2 & 1 & 1 & 4 \\
\hline $\begin{array}{l}\text { Subacute thrombosis } \\
\text { (no.) } \int\end{array}$ & 0 & 0 & 0 & 0 & 3 & 1 & 0 & 4 & 3 & 1 & 0 & 4 \\
\hline $\begin{array}{l}\text { Target-lesion } \\
\text { revascularization } \\
\text { for restenosis } \\
\text { at } 1-6 \text { mo (no.) }\end{array}$ & 1 & 2 & 2 & 5 & 1 & 0 & 0 & 1 & 2 & 2 & 2 & 6 \\
\hline Event-free (\%)** & 96 & 95 & 96 & 96 & 67 & 87 & 90 & 81 & 90 & 93 & 95 & 93 \\
\hline \multicolumn{13}{|c|}{$\begin{array}{l}\text { MI denotes myocardial infarction. } \\
\text { One patient in the control group, who was event-free, did not receive antiplatelet therapy after discharge and is not included in the table. } \\
\text { The non-Q-wave myocardial infarction occurred in the first } 30 \text { days. The infarction was related to side-branch closure during stenting. } \\
\text { pidogrel. } \\
\mathrm{P}<0.001 \text { for the effect of cilostazol as compared with that of clopidogrel. Event-free data were calculated on a per-patient basis (multiple } \\
\text { events occurred in some patients). } \\
\text { All non-Q-wave myocardial infarctions occurred in the first } 30 \text { days. } \\
\text { events occurred in some patients). }\end{array}$} \\
\hline
\end{tabular}

unless the patient's symptoms are untreatable with medication. Clinical experience at these and other centers suggests that late regression of the stenosis may occur without intervention. ${ }^{24-27}$ In addition, the predominantly simple lesions treated in the study may also contribute to the lack of difference in the rates of revascularization. However, conclu- sions regarding clinical effect are tentative in this study, whose size was based on an angiographic end point. Nevertheless, given the practice pattern, duration of follow-up, simplicity of lesions, and sample size, the angiographic benefit was not reflected in a beneficial difference in revascularization rates. The absence of late events also speaks to the is- 
sue of extended antiplatelet therapy. Although preclinical studies suggested a small delay in reendothelialization, ${ }^{28}$ in this clinical study, discontinuation of ticlopidine at one month was not associated with late thrombosis-related events between one and six months. Although the sample size was not sufficient to rule out the need for the extended therapy, there were no deaths, myocardial infarctions, or emergency surgeries between one and six months in the subgroup of 73 patients who received only aspirin after the first month. However, early events among the patients treated with cilostazol suggest that specific, effective antiplatelet therapy is required with antiproliferative-eluting stents.

The results of this study of paclitaxel are similar to those of the Randomized Study with the Sirolimus-Coated Bx Velocity Balloon-Expandable Stent in the Treatment of Patients with de Novo Native Coronary Artery Lesions (RAVEL) of sirolimus. ${ }^{7}$ Both demonstrate the potential of antiproliferative agents to reduce restenosis by inhibiting neointimal hyperplasia.

The study did not have sufficient power to identify infrequent risks, to define fully the need for extended antiplatelet therapy, to explain the observed effect of cilostazol fully, or to assess effectiveness in more complex lesions. The six-month follow-up period leaves unanswered the question of the du- ration of the benefits seen at six months and the possible long-term adverse effects of drug-eluting stents, whether the drug eluted is paclitaxel or another agent. Larger studies are needed to evaluate more adequately the clinical effect of the use of coated stents for the elimination of restenosis.

From these data, we conclude that paclitaxeleluting coronary stents significantly improved the angiographic outcome six months after percutaneous transluminal coronary intervention by reducing neointimal hyperplasia after stent placement, resulting in increased vessel diameter, reduced stenosis, and reduced binary restenosis at follow-up. Paclitaxel had a safety profile similar to that of the control stent when used with conventional antiplatelet therapy. The use of cilostazol appeared to be associated with subacute closure in a few patients. Of the dose densities tested, $3.1 \mu \mathrm{g}$ per square millimeter of abluminal stent surface was the more effective.

Supported by a grant from Cook.

Dr. Weissman reports having received a research grant from Medstar Research Institute, and Dr. Mintz reports having received lecture fees from Boston Scientific.

We are indebted to Dr. Jae-Joong Kim, Dr. Nam Sik Chung, Dr. Seong Yun Cho, and Dr. Yan Wang for their participation in this clinical trial; to Dong Soon Shin, Kyung Hea Park, and Young-Rok Han for research coordination; to Anthony O. Ragheb, Ph.D., for preclinical studies; and to Neal E. Fearnot, Ph.D., and William D. Voorhees, Ph.D., for trial direction and data analysis.
REFERENCES

1. Lowe HC, Oesterle SN, Khachigian LM. Coronary in-stent restenosis: current status and future strategies. J Am Coll Cardiol 2002; 39:183-93.

2. Hoffmann R, Mintz GS, Dussaillant GR, et al. Patterns and mechanisms of in-stent restenosis: a serial intravascular ultrasound study. Circulation 1996;94:1247-54.

3. Hanke H, Kamenz J, Hassenstein S, et al. Prolonged proliferative response of smooth muscle cells after experimental intravascular stenting. Eur Heart J 1995;16:785-93.

4. Moreno PR, Palacios IF, Leon MN Rhodes J, Fuster V, Fallon JT. Histopathologic comparison of human coronary in-stent and post-balloon angioplasty restenotic tissue. Am J Cardiol 1999;84:462-6.

5. Weissman NJ, Wilensky RL, Tanguay JF, et al. Extent and distribution of in-stent intimal hyperplasia and edge effect in a non-radiation stent population. Am J Cardiol 2001; 88:248-52.

6. de Feyter PJ, Vos J, Rensing BJ. Antirestenosis trials. Curr Interv Cardiol Rep 2000;2:326-31.

7. Morice M-C, Serruys PW, Sousa JE, et al. A randomized comparison of a sirolimus eluting stent with a standard stent for coronary revascularization. N Engl J Med 2002 346:1773-80.
8. Sousa JE, Costa MA, Abizaid AC, et al. Sustained suppression of neointimal proliferation by sirolimus-eluting stents: one-year angiographic and intravascular ultrasound follow-up. Circulation 2001;104:2007-11.

9. Rensing BJ, Vos J, Smits PC, et al. Coronary restenosis elimination with a sirolimus eluting stent: first European human experience with 6-month angiographic and intravascular ultrasound follow-up. Eur Heart 2001;22:2125-30.

10. Shiff PB, Fant J, Horwitz SB. Promotion of microtubule assembly in vitro by Taxol. Nature 1979;277:665-7.

11. Rowinsky EK, Cazenave LA, Donehowe RC. Taxol: a novel investigational antimicrotubule agent. J Natl Cancer Inst 1990, 82:1247-59.

12. Rowinski EK, Eisenhauer EA, Chaudhry V, Arbuck SG, Donehower RC. Clinical toxicities encountered with paclitaxel (Taxol). Semin Oncol 1993;20:Suppl 3:1-15.

13. Rowinsky EK, Donehower RC. Paclitaxel (Taxol). N Engl J Med 1995;332:100414. [Erratum, N Engl J Med 1995;333:75.]

14. Axel DI, Kunert W, Göggelmann C, et al. Paclitaxel inhibits arterial smooth muscle cell proliferation and migration in vitro and in vivo using local drug delivery. Circulation 1997;96:636-45.
15. Heldman AW, Cheng L, Jenkins GM, et al. Paclitaxel stent coating inhibits neointimal hyperplasia at 4 weeks in a porcine model of coronary restenosis. Circulation 2001; 103:2289-95.

16. Herdeg C, Oberhoff M, Baumbach A, et al. Local paclitaxel delivery for prevention of restenosis: biological effects and efficacy in vivo. J Am Coll Cardiol 2000;35:1969-76.

17. Sollott SJ, Cheng L, Pauly RR, et al. Taxol inhibits neointimal smooth muscle cell accumulation after angioplasty in the rat. J Clin Invest 1995;95:1869-76.

18. Yoon Y, Shim WH, Lee DH, et al. Usefulness of cilostazol versus ticlopidine in coronary artery stenting. Am J Cardiol 1999;84: 1375-80.

19. Park SW, Lee CW, Kim HS, et al. Comparison of cilostazol versus ticlopidine therapy after stent implantation. Am J Cardiol 1999;84:511-4.

20. Park SW, Lee CW, Kim HS, et al. Effects of cilostazol on angiographic restenosis after coronary stent placement. Am J Cardiol 2000; 86:499-503.

21. Kuntz RE, Safian RD, Carrozza JP, Fishman RF, Mansour M, Baim DS. The importance of acute luminal diameter in determining restenosis after coronary atherectomy or stenting. Circulation 1992;86:1827-35. 
22. Condado JA, Waksman R, Calderas $\mathrm{C}$, Saucedo J, Lansky A. Two-year follow-up after intracoronary gamma radiation therapy. Cardiovasc Radiat Med 1999;1:30-5.

23. Teirstein PS, Massullo V, Jani S, et al. Three-year clinical and angiographic follow-up after intracoronary radiation: results of a randomized clinical trial. Circulation 2000;101:360-5.

24. Kimura T, Abe K, Shizuta S, et al. Longterm clinical and angiographic follow-up after coronary stent placement in native coronary arteries. Circulation 2002;105:2986 91.

25. Lee JH, Lee CW, Park SW, et al. Longterm follow-up after deferring angioplasty in asymptomatic patients with moderate noncritical in-stent restenosis. Clin Cardio 2001;24:551-5.

26. Ormiston JA, Stewart FM, Roche AH, Webber BJ, Whitlock RM, Webster MW. Late regression of the dilated site after coronary angioplasty: a 5-year quantitative angiographic study. Circulation 1997;96:468-74. 27. Hermiller JB, Fry ET, Peters TF, et al. Late coronary artery stenosis regression within the Gianturco-Roubin intracoronary stent. Am J Cardiol 1996;77:247-51.

28. Farb A, Heller PF, Shroff S, et al. Pathological analysis of local delivery of paclitaxe via a polymer-coated stent. Circulation 2001, 104:473-9.

Copyright () 2003 Massachusetts Medical Society. 